\title{
Influence of Cultural Organization and Leadership on the Performance of Employees Mediated Job Satisfaction on District Health Department Mimika Papua
}

\author{
Adolf Halley, B Kambuaya, J Ronsumbre, Ferdinand Risamasu \\ University of Cendrawasih, Papua, Indonesia \\ pusdip.uncen@mail.com
}

\begin{abstract}
Cultural organizations have become the talk very interesting and very important in today's era. Not just in depth but in order to make changes continuously, making the competitive advantage and the ability to survive in an era of constantly changing. If an organization is not treated culture then the organization can certainly run into problems which ultimately affect the sustainability of the organization. Organizational culture becomes a key element of the changes that will be a huge impact for the working system of the organization. The purpose of this study is; (1) To examine and analyze organization with cultural influence, directly or indirectly through job satisfaction on the performance of employees at the Department of Health Government of Mimika District of Papua Province (2) To examine and analyze the effect leadership directly or indirectly through job satisfaction on the performance of employees at the Department of Health Government of Mimika District of Papua Province. (3) To examine and analyze the effect job satisfaction on the performance of employees at the Department of Health Government of Mimika District of Papua Province. Unit sample in this study were clerks in Mimika District Health Office. Respondents amounted to 259 employees, were taken using the convenient sampling method. Data were analyzed using Structural Equation Modeling (SEM) with the help of the program Analysis of Moment Structure (AMOS). The results showed that. The results showed that organizational culture and positive significant influence on employee performance both directly and indirectly through job satisfaction. It shows that when organizations are paying attention and make improvements to the organization's culture will directly be able to increase job satisfaction and indirectly affect employee performance. Leadership and positive significant effect on employee performance, both directly and indirectly through job satisfaction. It shows that the improvement of leadership in the organization will directly improve the performance of employees or indirectly through job satisfaction. Job satisfaction had positive significant influence on employee performance. This means that increasing employee satisfaction will be able to improve employee performance.
\end{abstract}

\section{Keywords: Organizational Culture, Leadership, Job Satisfaction, Employee Performance}

\section{Introduction}

Just like people following things may happen in an organization. First, membership of an organization generally derived from individuals with different backgrounds, values and culture. Second, each member of the organization can be said to be free from values for before joining the organization. They have values and culture adopted from the values and culture of the people outside the organization. Third, as a society then within organizations takes social interaction between members. As a result, the relationship between them is not just a formal relationship, but more than that could be more informal and emotional and cultural. The results of research show that the strength of the organizational culture has an impact on job satisfaction which leads to individual performance and overall organizational performance. Organizational culture is the values, attitudes, and beliefs that control the actions and behavior of individuals within the organization (Stonehouse \& Pemberton, 1999). Organizational culture shaping employee orientation towards work and determine the extent to which employee behavior directed at achieving the goals that the set is organizational rather than on their personal interests (Grindle, 1997). Theoretically, organizations are performing well and performing to have a different culture (Grindle, 1997). Organizations that have performed well (good performers organization) has the dimensions of a positive culture that embraced strongly by most members. Cultural criteria strong or dominant culture of the organization is the organization's core values embraced by the powerful, well organized, and implemented jointly by members of the organization are widely (Robbins, 1994). An organization's culture is said to be strong when many members of the organization that receives the core values of the approved range of its importance, and feel very attached to him (Robbins, 1994). Strong organizational culture provides direction and strength the standards of conduct to control the perpetrators of the organization to carry out the duties and responsibilities they effectively and efficiently to achieve the goals and objectives of the organization that has been agreed (Luthans, 2006). 
The success of an organization in achieving its objectives depends on the leadership, namely whether the leadership is capable of moving all the human and natural resources, facilities, funds, and time effectively and efficiently in a management system is to make employees as partners than as subordinates (partnership management), This is in line with the opinion of Thoha (2001) suggested that, in order to maintain the life and dynamism of the organization (Organizational survival), every organization would not want to be adaptive to change. Organizations that are able to compete in the future are those that have the human resources based on knowledge by having a range of skills and expertise (multi-skilling workers). As a government organization, Mimika District Government has its own distinct culture of the organization with government organizations in other areas outside the province, in particular to the influence of local culture. Character and style lead still very in touch with the tradition of tribal leaders originated. Organizational culture and leadership style is a reflection of the local culture that is still very dominant. It is also assumed to have an influence on employee satisfaction, because the organizational culture is a basic conviction underlying vision and mission, purpose and values espoused by the organization's members from the leadership to employees at the lowest level that will provide direction or guidance behave. In addition to the leadership style of the leaders who generally also have a kinship with tribal leaders in Papua so that the leadership style and culture is still very strong, especially associated with employees coming from the same tribe as the leader. goals areas of research: (1) To test and analyze the cultural influence organization directly or indirectly through job satisfaction on the performance of employees at the Department of Health Government of Mimika District of Papua Province (2) To examine and analyze the effect leadership directly or indirectly through job satisfaction to employee performance at the Government Health Service District Mimika Papua Province. (3) To test and analyze the effects of job satisfaction on the performance of employees at the Department of Health Government of Mimika District of Papua Province.

\section{Literature Review}

Organizational culture: Linkages and organizational culture can be analyzed at three points of view: (1) culture is a product of a market context where the organization operates, regulatory pressing and so on; (2) culture is a product of the structure and functions within the organization, such as centralized organization differs from a decentralized organization; (3) culture is a product of the attitudes of people in their work, it means the product of psychological agreement between individuals and organizations (Graves and Desmond, 1986: 45). The concept of organizational culture is still relatively new, about the beginning of the 1980s the term organizational culture gaining popularity, two scientific journals, namely administrative science Quarterly (ASQ) and Organizational Dynamics (OD) in 1983 published a special edition to make the writings of the organizational culture to popularize the term organizational culture with use the term organizational culture with the use of the term organizational symbols/Symbolism, manager symbols / Symbolism, organizational culture, corporate culture. Anthropology is the discipline that has long been concerned with the general idea of the culture. Some people argue that organizational culture is very still studied in anthropology tradition by using qualitative methods Schein, Edgar (1992). However Thus, this adult rides organizational culture literature has been developed in various used in the study of organizational culture (Jaskyte \& Dressler, 2005). Organizational culture is often understood as a construct that is profound because he respect to the meaning, assumptions, beliefs and values that are commonly understood by members of the organization (Glisson, 2002; Glisson \& James, 2002). Organizational culture is often seen as an organizational constructs and variables in organizational studies (Glisson, 2002).

Leadership: Broadly speaking, leadership is seen from its approach and perspective, according to Yuki (1998) consists of; (1) Approach trait (Trait Approaches); (2) Approach Behavior (Behavior Approaches): (3) Situational Approach (Situational Approaches); and (4) Approach Effect of Power (Power-influence Approaches). Trait theory approach (Trail Approaches) basically emphasizes the aspects of the personality of a leader, among others, intellectual, physical, emotional and other personal properties of nature. According to this theory, some individuals are born with certain properties that will keep them on the situation or particular historical period emerged as a leader (Luthans, 1998). Approach behavior (Behavior Approaches) is a theory which states that specific behaviors differentiate a leader who is not a leader (Robbins, 2001), ".... Specific behaviors differentiate leaders from non-leaders". Some of the leading theorists in the group approaches include: (1) Haw tome Studies by Douglas McGregor's famous theory X and Y, (2) The Iowa Leadership Studies, at the end of the 1930s, led by Ronald Lippil and Ralph K. White that analyzing leadership 
styles autocratic, democratic and laissez-faire, (3) the Ohio State leadership Studies (1945), led by Edwin Fleishman that identifies two major functions of leadership that consideration and the initiator of structure (consideration and structure), (4) the Early Michigan Leadership studies (1947), which ultimately resulted in "System 4" based on research conducted by Rensis Likert, and (5) Blake and Mauton's Managerial / Leadership Grip (Kreitner and Kinicki, 1998). Situational approach (Situational Approaches) according Ivanceich and Matterson (1999) gave a statement that leadership effectiveness is a function of various aspects of the leadership situation, "..., leadership effectiveness is a function of various aspects of the leadership situation" in which the leader's style should suit the current situation is situational approach will be also known as Contingency theory (Contingency theories). Theories are also included in this group include the cognitive approach, cross-cultural approaches and theories of leadership substitution (Luthans, 1998; Robbins, 2001; Kreitner, 1998).

\section{Figure 1: Cultural organizations have an impact on performance and satisfaction}

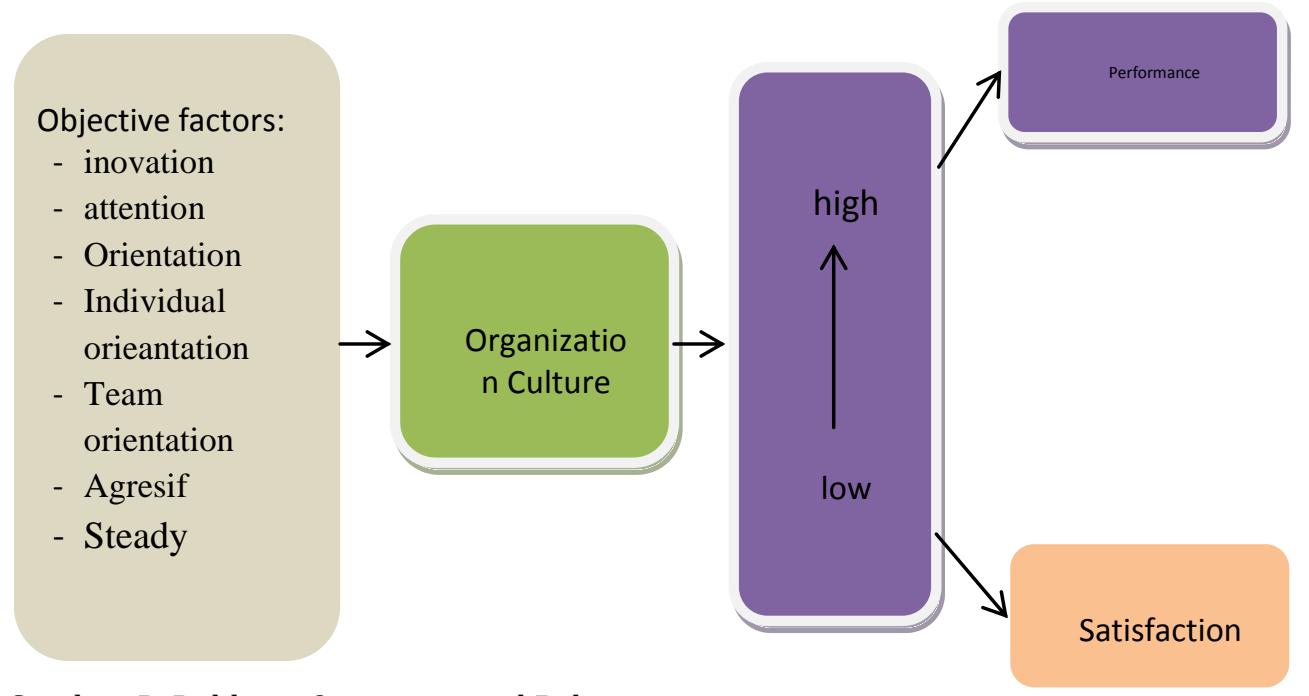

Source: Stephen P. Robbins, Organizational Behavior

The concept of Employee Job Satisfaction: Talking about job satisfaction, actually has a lot of research done by experts, for example, Handoko (2000), which says personnel and human resources, "job satisfaction (job satisfaction) is an emotional state that is pleasant or unpleasant in which employees view their job as a liability. Job satisfaction reflects a person's feelings toward his work, is seen in the positive attitude of employees towards work and everything encountered in the work environment ". Actually the term satisfaction is an image abstract and difficult to define. Job satisfaction is one aspect that affects performance. Is something natural that every company expected employees have always tried to keep morale high, because then the expected enthusiasm and excitement to work may increase. In an effort to improve employee satisfaction, it is proper if the leadership is able to create opportunities for subordinates to improve performance, provide a reasonable award, giving broader responsibilities again or the opportunity to developing themselves. Job satisfaction is an emotional state that is pleasant or unpleasant in which employees view their job. Job satisfaction reflects one's feelings toward his work. Job satisfaction is evident in the positive attitude of employees towards work and everything encountered in the work environment (Handoko, 2000).

Robbins (1995), the expression of that job satisfaction is a general attitude towards work, the difference of numbers of rewards earned by an employee with the amount they believe they should receive. Employees who are satisfied will be more productive than employees who are not satisfied a basic teaching among leaders over the years. Besides job satisfaction can also be interpreted as an effective or emotional response to various aspects of the work (Kreitner, 2005). Emotional state of pleasant or unpleasant workers views their job (Handoko, 2000). Job satisfaction is a way to actuating themselves, so that it will achieve a psychological maturity on the employee. If satisfaction is not achieved, then it can happen possibility would be frustrated employees (Handoko, 2000). Malay Hasibuan (1995) defined job satisfaction as an emotional 
attitude of fun and love the work of employees who did not receive job satisfaction will never achieve psychological maturity, and in turn will become frustrated. Davis, K \& John, W. Newstrom, (1996) suggested that job satisfaction is a great feeling, or not perceived by employees in looking at the work, "Job Satisfaction is the favorableness or unfavorable with employees view Reviews their work". E. A Locke as quoted by Luthans (1998) provides a definition of satisfaction as "a pleasurable or positive emotional state the resulting from the appraisal of one's job or job experience", job satisfaction is a feeling pleasant or positive, the result of an assessment of a person's job or work experience.

Based on the opinions of the above, it can be said that job satisfaction is a result of employee perceptions either pleasant or not, as to how well they produce something that is considered to be important for the company. While New Davis \& John, Newstrom (1996) states that several studies to separate the factors that influence job satisfaction into two parts, namely the factors directly relate with Job Content (type of work) and those associated with the Job Context (supervision, co-workers and organizations ). Factors that influence job satisfaction an employee found in two factors, namely: (1) concerning the feelings of employees on the job, namely the nature and type of work, supervision, payroll system, opportunities for career development, staffing, relationships with colleagues, structure organization of the company, and (2) that concern employees such as age, health condition, sex, education, work experience, think, work attitude and so on. Smith, Kendall and Hulin as quoted by Luthans (1998) made a statement that there are five dimensions that can affect satisfaction Keria, namely: (1) the work itself; whether the work provides an interesting task for employees, (2) the payment system / payroll; namely a number of financial payment received at a level perceived to be fair in the company, (3) the opportunity to be promoted, (4) monitoring; the ability of providers to provide technical assistance and support, and (5) co-workers; co-workers were friendly and cooperative will affect an employee job satisfaction.

\section{Methodology}

Research sites: The location of this research will be conducted in Mimika Regency of Papua Province with a focus on the SKPD that the Department of Health. Mimika regency has different characteristics with other districts in the province.

Types and Sources of Data: The types and sources of data in this study are: primary data and secondary data. Making procedures and collection of both types of data is done as follows: Primary data obtained from the distribution of questionnaires to each respondent in the survey locations respective secondary data on the number and types of organizations at each study site and employee profile data, obtained at each study site.

Operational Definition of Variables: This study uses four variables Cultural Organization (BO) and Leadership (KP) as exogenous, Job Satisfaction (KK) and Employee Performance (KN) as an endogenous variable. Here is the operational definition and measurement of each variable selected:

Population and Sample: The population in this study was all employees of the Department of Health Government of Mimika District, where the number of population on education amounted 735. Based on the formula obtained a sample as follows: Population $(\mathrm{N})$ as much as 735 people assuming error rate $(\mathrm{e})=5 \%$, then the number of samples $(\mathrm{n})$ is:

$$
\begin{aligned}
& \mathrm{n}=\frac{735}{1+735(0,05)^{2}} \\
& \mathrm{n}=\frac{735}{2,8375}=259,03 \\
& \mathrm{n}=259
\end{aligned}
$$

In the sampling questionnaires were returned and worth taking as many as 259 . Some respondents were then conducted sampling technique: Sampling where taken Mimika Health Department unit that can be reached by considering the distribution of samples are: 1) Employees who are civil servants in the 
Department of Health SKPD Mimika regency government. 2) An employee who is a Labor Contract, PTT and Voluntary Workers in the sectors of Education and Health sectors Mimika regency government.

Table 1: Summary of variables, operational definitions and indicators

\begin{tabular}{|c|c|c|c|c|}
\hline No. & Variable & Operational definition & indicators Research & Source \\
\hline 1 & $\begin{array}{l}\text { Organizational } \\
\text { culture }\end{array}$ & $\begin{array}{l}\text { Organizational culture is a common } \\
\text { perception shared by members of } \\
\text { the organization about the values } \\
\text { that are acceptable and which are } \\
\text { not received within the } \\
\text { organization. }\end{array}$ & $\begin{array}{l}\text { a) Innovation and } \\
\text { taking } \\
\text { b) Attention in detail } \\
\text { c) orientation results } \\
\text { d) The orientation o } \\
\text { individual } \\
\text { e) Group Orientation } \\
\text { f) Aggressiveness } \\
\text { h) Stability }\end{array}$ & $\begin{array}{l}\text { risk- Robbins (1994) } \\
\text { f the }\end{array}$ \\
\hline 2 & Leadership & $\begin{array}{l}\text { Leadership is an art as well as the } \\
\text { ability to influence other people's } \\
\text { backs, without coercion, to do what } \\
\text { is expected or desired leadership in } \\
\text { achieving a goal. Ethnic cultural } \\
\text { background influence the style }\end{array}$ & $\begin{array}{l}\text { a.Take effect } \\
\text { b.Having great soul } \\
\text { c. Concerned Crowd } \\
\text { d. Example } \\
\text { e. Unite } \\
\text { f. Sportsmanlike } \\
\text { g. Courageous } \\
\text { hesolute } \\
\text { h. Generous } \\
\text { i. Courteous }\end{array}$ & $\begin{array}{l}\text { Kambu Arius } \\
\text { (2011) } \\
\text { Tedjo (2013) *he } \\
\text { value of positive } \\
\text { cultures need } \\
\text { and }\end{array}$ \\
\hline 3 & Job satisfactior & $\begin{array}{l}\text { Job satisfaction is a feeling that } \\
\text { there is satisfaction right and there } \\
\text { were no unpleasant perceived in } \\
\text { the employee sees its job. }\end{array}$ & $\begin{array}{l}\text { a) The work itself } \\
\text { b) payroll system } \\
\text { sale opportunities } \\
\text { d) Monitoring } \\
\text { e) Co-Workers }\end{array}$ & $\begin{array}{l}\text { Smith, Kendal \& } \\
\text { Hullin in Luthans } \\
\text { (1998) }\end{array}$ \\
\hline
\end{tabular}

$\begin{array}{lll}4 \text { Employee } & \text { Performance is the willingness of a a.Quality } & \text { Andraeni, } \\ \text { performance } & \text { person or group of people to carry b.Quantity } & \text { Nyoman } \\ & \text { out activities or improve it in c.Punctuality } & \text { Novitasari. } \\ \text { accordance with its responsibilities } & \text { (2003) } \\ & \text { with results. } & \text { A.A. Anwar Prabu } \\ & & \text { Mangkunegara. } \\ \end{array}$

Method of collecting data: Methods of collecting data are done by using a survey method through questionnaires distributed to the study sample which contains questions about the study variables. The data collection technique used was a questionnaire enclosed is a list of questions which alternative answers are provided so that the respondent can just choose. The questionnaire was made using a scale of the manner in which emphasis on measuring the attitudes, the Likert scale.

Data Analysis Methods: The quantitative analysis used in this research is the analysis of descriptive and inferential statistical analysis in the form of structural equation modeling (Structural Equation Modeling-), in which the model is based on causal relationships (Hair et al., 2006). The use of descriptive analysis is intended to obtain information about the respondents' perception to construct various indicators of organizational culture, leadership, job satisfaction, and employee performance. Information on employee perceptions then used as a basis to clarify the contribution of each item to the variable constructs (latent). Meanwhile, the use of SEM as an analytical tool based on reasons other than the hassle of the model 
used, also based on the limitations of the multidimensional analysis tools that are often used in quantitative research such as multiple regression analysis, factor analysis.

Analysis of Structural Equation Model: The construct was built in the path diagram can be divided into two types as follows;

- $\quad$ Constructs exogenous (exogenous constructs), known also as the source variable or variables that are not predicted by other variables in the model.

- Constructs endogenous (endogenous constructs), are all factors that predicted by a single or multiple constructs. Constructs endogenous can predict one at a u some other endogenous constructs, but endogenous constructs can only be associated causally with endogenous constructs. Model track relationships between constructs can be described as follows in the path diagram.

Figure 1: path diagram

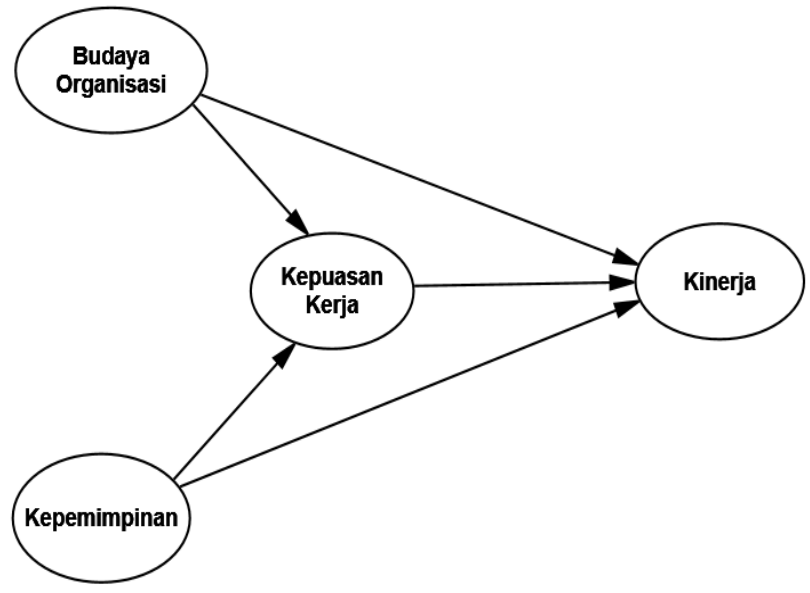

\section{Results and Discussion}

Organization Cultural Influence Direct and Indirect through Performance against to Employee Job Satisfaction: The results showed that organizational culture is a significant and positive effect on employee performance, both directly and indirectly through job satisfaction. This means that the improvement in the organizational culture can directly improve employee performance. Similarly, the improvement of organizational culture may indirectly improve employee performance through improved employee satisfaction. The results of the study indicated that organizational culture significant and positive impact on employee performance is in line with research findings Eddy (2010) which states that the organizational culture significant and positive impact on employee performance.

Leadership influence Indirect through Performance Against to Employee Job Satisfaction: The results of this study indicated that organizational culture significant and positive impact on employee performance, both directly and indirectly through job satisfaction. This means that the improvement in the organizational culture can directly improve employee performance. Similarly, the improvement of organizational culture may indirectly improve employee performance through improved employee satisfaction. The results mentioned above support the research findings Soedjono (2005) with the title "The Influence of Organizational Culture on Performance and Job Satisfaction in the Passenger Terminal General Surabaya ", where the result is that organizational culture significant and positive impact on performance, as well as organizational culture significant and positive impact on employee job satisfaction. The study's findings are also in line with the results of research Sitti Haerani, Nurjannah Hamid and Agus Yulianto (2012) with the title: Application Distribution Method Forced in the Assessment of Performance and Cultural Organization and the Implications Job Satisfaction and Employee Performance, which found organization culture significant and positive impact both directly or indirectly (through job satisfaction) against, performance, job satisfaction significant and positive impact on employee performance. The results of this 
study are also consistent with the findings of the study Eddy (2010) which states that the organizational culture significant and positive impact on employee performance.

Effect of Job Satisfaction on Performance: The results showed that significant influence job satisfaction and employee performance positive. That is, increasing employee satisfaction is measured through: the work itself; teaching system; opportunity promoted; supervision; and colleagues can improve employee performance is measured through indicators of time; quality; and quantity. Results were above reject research findings S Alf Crossman, Bassem Abou-Zaki, (2003) titled "Job Satisfaction and employee performance of the Lebanese banking staff", where the study found that job satisfaction is not significant effect on performance.

\section{Conclusion}

The results showed that improve employee satisfaction, it is proper if the leadership is able to create opportunities for subordinates to improve performance, provide a reasonable award, giving broader responsibilities again or the opportunity to develop themselves. Job satisfaction is an emotional state that is pleasant or unpleasant in which employees view their job. Job satisfaction reflects one's feelings toward his work. Job satisfaction is evident in the positive attitude of employees towards work and everything encountered in the work environment.

\section{References}

A.A. Anwar Prabu Mangkunegara. (2001). Manajemen sumber daya manusia perusahaan, Bandung: Remaja Rosdakarya.

Andraeni, Nyoman Novitasari, N. (2003). Pengaruh Stres Kerja Terhadap Motivasi Kerja dan Kinerja Karyawan PT. H.M Sampoerna Tbk Surabaya,Tesis. Universitas Airlangga, Surabaya

Davis, K. \& John, W. N. (1996). Organizational behavior, Volume I, Erland, Jakarta.

Eddy, Y. (2010). Effect of Leadership, Individual and Organizational Culture on Employee Performance Department of Culture and Tourism and Customer Satisfaction of tourism industry in East Java. Application Management Journal, 8(4), 961-970

Glisson, C. (2002). The Organizational Context of Children's Mental Health Services, 5(4).

Glisson, C. \& James, L. R. (2002). The Cross-Level Effects of Culture and Climate in Human Services Teams. Journal of Organizational Behavior, 23(6).

Graves \& Desmond. (1986).Organization Behavior. McGraw-Hill Inc. New York.

Grindle, M. S. (1997). Getting Good Government: Capacity Building in the Public Sector of Developing Countries, Boston, MA : HArvard Institue for International Development.

Hair, A. (2006). Multivariate Data Analysis $6^{\text {th }}$ Ed. New Jersey: Pearson Education

Handoko, H. (2000). Personnel Management and Human Resources, Yogyakarta. BPFE.

Hasibuan, M. S. P. (1995). Manajemen Sumber Daya Manusia: Dasar dan Kunci Keberhasilan, Jakarta: Toko Gunung Agung.

Ivancevich, J. M. \& Matteson, M. T. (1999). Organizational Behavior and Management. Singapore: Irwin/McGraw-Hill.

Jaskyte, K. \& Dressler, W. W. (2005). Organizational Culture and Innovation in Non-profit Human Service Organizations. Administration in Social Work, 29(2), 23-41.

Kambu, A. D. (2011). Pengaruh Leader-Member Exchange, persepsi Dukungan Organisasional, Budaya Etnis Papua dan

Organizational Citizenship Behavior , terhadap Kinerja Pegawai pada Sekda Provinsi Papua ISSN : 1693-5241

Kreitner, R. \& Angelo, K. (1998). Organizational Behavior: Key Concepts, Skills and Best Practices. Mc GrawHill Company, New York.

Kreitner, R. \& Angelo, K. (2005). Organization Behavior: Organizational Behavior, Publisher Salemba Four, Jakarta

Luthans, F. (1977). Organization Behavior, Tokyo: Mc. Graw-Hill, LTD.

Luthans, F. (1998). Organisasi Behavior, Eighth Edition, McGraw-Hill Intemasional Book Company, New York

Luthans, F. (2006). Organizational Behavior. Paper Back, Revised. 
Robbins, S. P. (1994). Teori Organisasi : Struktur, Desain, dan Aplikasi, Edisi Ketiga, Alih Bahasa Jusuf Udaya, Arcan, Jakarta.

Robbins, S. P. (2001). Psikologi Organisasi, (Edisi ke-8). Jakarta: renhallindo.

Saif, C. \& Abou-Zaki, B. (2003). Job satisfaction and employee performance of Lebanese banking staff. Journal of Managerial Psychology, 18(4), 368-376

Schein, E. H. (1992). Organizational Culture and Leadership, Jossey Bass, San Francisco.

Siti Haerani, N. H. \& Yulianto, A. (2012). Aplikasi Metode Distribusi Paksa Dalam Penilaian Kinerja Dan Budaya Organisasi Serta Implikasinya Terhadap Kepuasan Kerja Dan Kinerja Karyawan Pt Bank Mandiri (Persero), Tbk.Area Jember, Jurnal Magister Manajemen Unhas

Soedjono. (2005). Examined the Influence of Organizational Culture and Organizational Performance against Employee Satisfaction at the Passenger Terminal General in Surabaya. Journal of Management and Entrepreneurship, 7, 22-47.

Stonehouse, G. H. \& Pemberton, J. D. (1999). Learning and knowledge management in the intelligent organization. Participation \& Empowerment

Thoha, M. (2001). Leadership in Management. PT. King Grafindo Persada, Jakarta.

Tedjo, S. (2013). Role of Ethnic Culture in Leadership at the Provincial Government of Papua, Doctoral Dissertation Science and Business Management, Faculty of Economics, University of Brawijaya.

Yukl, G. A. (1998). Leadership in Organizational, 4th Ed. Prince Hall, Upper Saddle River, NJ. 